\title{
EDUKASI KESIAPSIAGAAN BENCANA MENINGKATKAN PEMAHAMAN PROSEDUR PENYELAMATAN DIRI
}

\author{
Telly Rosdiyani \\ Universitas Banten Jaya, J1 Syech Nawawi Albantani Serang, Banten, Indonesia \\ Email: tellyrosdiyani004@gmail.com
}

\begin{abstract}
Teneng village, Cinangka village has an area of 711,110 Ha. The land is intended for the land of public, social, residential, agricultural, plantation and most land for fisheries because the geographical location of the Cinangka village is close to the coast. This area is including potential earthquake and even tsunami. From this basis, the aim of the Community Service Program is to provide a real life rescue education program to improve the understanding of village community skills in disaster preparedness. The partner of this activity is the Regional Disaster Management Agency (BPBD), the problem faced is that the public does not know the correct procedures for self-rescue against disasters, has not been able to control the panic of a sudden and impending disaster. The method of implementing this service is through (1) Surveying through observation, interviews, and analysis of village problems and potentials, (2) Counseling and simulation of disaster response. The result of this program is to increase the community's knowledge and skills regarding disaster preparedness and to be able to exercise self-control from the fear of disasters to be able to reduce disaster victims. The program is also expected to facilitate the community of information and skills in disaster preparedness.
\end{abstract}

Keywords: Training; Community Empowerment; Disaster Preparedness.

\begin{abstract}
ABSTRAK
Kampung Teneng, kelurahan Cinangka mempunyai luas 711.110 Ha. Lahan tersebut diperuntukkan untuk tanah fasilitas umum, sosial, pemukiman, pertanian, perkebunan dan paling besar diperuntukkan tanah perikanan karena letak geografis kelurahan Cinangka dekat dengan pesisir pantai. Cinangka termasuk jalur potensi gempa bahkan terjadinya tsunami. Dari dasar tersebut tujuan Program Pengabdian Masyarakat Kuliah Kerja Nyata memberikan pembekalan edukasi posedur penyelamatan diri untuk meningkatkan pemahaman keterampilan Masyarakat Desa terhadap kesiapsiagaan bencana. Mitra dari kegiatan ini adalah Badan Penanggulangan Bencana Daerah (BPBD), permasalahan yang dihadapi yaitu masyarakat belum mengetahui prosedur penyelamatan diri yang benar terhadap bencana, belum dapat mengendalikin rasa panik adanya bencana yang tiba -tiba datang. Metode pelaksanaan pengabdian ini yaitu melalui (1) Survey melalui pengamatan, wawancara, dan analisis permasalahan dan potensi desa, (2) Penyuluhan dan simulasi tanggap bencana. Hasil dari program ini adalah bertambahnya pengetahuan dan keterampilan masyarakat mengenai kesiapsiagaan bencana serta dapat melatih pengendalian diri dari rasa takut bencana untuk dapat mengurangi korban bencana, Program ini pun diharapkan dapat memfasilitasi masyarakat informasi dan keterampilan dalam kesiapsiagaan terhadap bencana.
\end{abstract}

Kata Kunci: Pelatihan; Pemberdayaan Masyarakat; Kesiapsiagaan Bencana. 


\section{PENDAHULUAN}

Kampung Teneng Kelurahan Cinangka Kecamatan Cinangka Kabupaten Serang yang terletak $49 \mathrm{Km}$ dari Kantor Pusat Pemerintahan Provinsi Banten, dan 5,2 Km dari Kantor Kecamatan Cinangka dengan jumlah penduduk sebesar 1508 jiwa/orang. Batas wilayah Kelurahan Cinangka Kecamatan Cinangka Kabupaten Serang terdiri dari bagian utara, berbatasan dengan Desa Sindang Laya, bagian selatan, Berbatasan dengan Desa Karang Suraga, Timur, berbatasan dengan Desa Kubang Baros, Barat, berbatasan dengan Selat Sunda. Dengan gambaran ilustrasi tersebut menunjukkan desa yang aktif serta lokasi kampung Teneng tidak jauh dari pesisir pantai.

Pada bulan Desember 2018, daerah ini telah mengalami bencana tsunami yang disebabkan oleh letusan anak krakatau di selat sunda sehingga menghantam daerah pesisir banten. Edukasi kesiapsiagaan bencana menjadikan sesuatu yang penting dibutuhkan masyarakat di lokasi daerah tersebut. Dengan Kondisi tersebut maka Kuliah Kerja Mahasiswa (KKM) atau Kuliah Kerja Nyata (KKN) Universitas Banten Jaya (UNBAJA) dijadikan salah satu program dalam pendidikan tinggi dalam bentuk kegiatan pengabdian masyarakat oleh mahasiswa dan dosen pembimbing lapangan dengan pendekatan lintas keilmuan dan sektoral pada waktu dan daerah tertentu. KKM kelompok 9 (sembilan) dilakukan oleh Universitas Banten Jaya ditempatkan dikabupaten Serang berlokasi di kecamatan Cinangka, desa Cinangka merupakan KKM (KKN) tematik berbasis Problem Solving untuk memecahkan masalah dengan tema "Teknologi Tepat Guna, Kewirausahaan dan Pengembangan Budaya Banten “,penulis tertarik untuk melakukan suatu program edukasi keseiapsiagaan bencana pada masyarakat kampung Teneng Desa Cinangka ini.

Edukasi penangan bencana merupakan suatu bentuk kegiatan dalam memberikan pemahaman langkah awal untuk menyelamatkan diri dan mencari tempat aman pada saat terjadinya bencana. Edukasi ini suatu pelatihan dan simulasi supaya waktu terjadinya bencana alam diharapkan masyarakat, anak-anak dan lainnya sudah terbiasa sehingga dapat mengurangi dampak kepanikan.

\section{Bencana Alam}

Bencana alam merupakan suatu peristiwa alam yang mengakibatkan dampak besar bagi populasi manusia. Bencana alam bisa berupa gempa bumi, banjir, letusan gunung merapi, tsunami, tanah longsor, badai salju, gempa bumi, kekeringan dan lainnya. Gempa bumi merupakan getaran atau guncangan yang terjadi dipermukaan bumi yang disebabkan oleh tumbukan antar lempeng bumi, sedangkan Letusan gunung api merupakan bagian dari aktivitas vulkanik yang dikenal erupsi hal ini biasanya berupa awan panas, lontaran material, lava, gas racun, lahar serta tsunami. Tsunami itu sendiri merupakan berasal dari bahasa jepang yang artinya ombak lautan dengan ejaan Tsu 
artinya lautan dan nami adalah gelombang ombak jadi tsunami ini merupakan serangkaian gelombang ombak lautan yang timbul karena adanya pergeseran di dasar laut akibat adanya gempa bumi.

Upaya pengurangan risiko bencana dilakukan pertimbangan dari beberapa aspek diantaranya aspek keberlanjutan dan partisipasi semua elemen masyarakat (Pahleviannur, 2019) serta menurut (Suriadi et al., 2008) menerangkan dengan latihan kesiapsiagaan bencana dapat memahami resiko, mengelola ancaman dan bahkan bisa berkontribusi dalam mendorong ketangguhan masyarakat dari ancaman bahaya bencana. Disamping itu kohesi, sosial, gotongroyong dan saling percaya merupakan nilai perekat modal sosial yang telah teruji.

\section{METODE}

Metode yang digunakan dalam edukasi kesiapsiagaan bencana diantaranya adalah (1) Menghubungkan kepada mitra BPBD dan Pusdalops-Pb dan badan yang terkait untuk dapat memberikan materi kepada masyarakat (2) Pelaksanaan pelatihan sekaligus simulasi pada masyarakat di kampung Teneng yang diawali dengan pemberian materi menyampaikan tentang penanggulangan bencana gempa bumi dan tsunami.

\section{Langkah-langkah Keiapsiagaan Bencana}

Tahapan utama yang harus dilakukan dalam suatu kesiapsiagaan bencana terdiri dari beberapa tahapan yaitu tahapan perencanaan, pelaksanaan serta monitoring dan evaluasi.

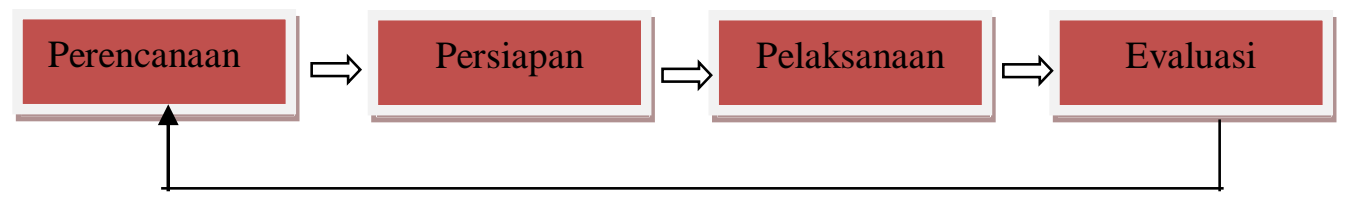

Gambar 1. Proses Tahapan Kesiapsiagaan Bencana

Simulasi kesiapsiagaan bencana dapat meminimkan korban bencana. Tahap perencanaan pertama dengan membentuk organisasi/tim perencanaan desa Cinangka, hal ini dimaksudkan dapat merumuskan strategi pelaksanaan tanggap bencana yang mengintegrasikan beberapa kegiatan yang menjadi kegiatan rutin dalam jangka panjang. Dalam penyusunan perencanaan penanggulangan bencana mempertimbangkan terhadap langkah-langkah penanggulangan bencana yang pertama adalah pengenalan terhadap jenis-jenis bencana, kemudian pengenalan kerentanan titik potensi bencana, menganalisis kemungkinan dampak, pemilihan tindakan penanggulangan, mekanisme 
panggulangan dampak bencana selanjutnya mengalokasikan tugas dan peran instansi. Contoh mensikapi bencana gempa bumi, bagaimana cara bersikap ketika terjadi gempa bumi, langkah apa yang harus dilakukan ketika terjadi gempa bumi salah satunya adalah dengan mengenali jenis gempa bumi tersebut, misalnya jika gempa di bawah 3,0 SR maka tidak perlu keluar rumah tapi apabila lebih dari itu segera bergegas untuk keluar rumah, atau berlindung di bawah meja, pergi ke tempat terbuka seperti lapangan jika gempa itu berkekuatan di atas 5,0 SR, (Roskusumah, 2013)

\section{Alat, Bahan Simulasi Pelatihan}

Alat dan bahan dalam pelatihan kesiapsiagaan bencana merupakan suatu alat peraga sederhana yang disiapkan oleh penitia penyelenggara dan narasumber terkait untuk meningkatkan pemahaman materi.

\section{HASIL DAN PEMBAHASAN}

\section{Pelaksanaan Pelatihan}

Kegiatan ini dilaksanakan aula kampung Teneng Desa Cinangka kecamatan Cinangka Provinsi Banten. Sebanyak 69 warga masyarakat Teneng, yang antusias menghadiri acara seminar penyuluhan dan penangulangan bencana bersama BPBD (Badan Penangulangan Bencana Daerah) yang dilaksanakan hari Jumat tanggal 21 Agustus 2019 di aula kampung Teneng. Acara ini tunggutunggu masyarakat dan diperlukan bahwasanya kampung Teneng merupakan salah satu dari desa Cinangka termasuk wilayah dampak bencana tsunami yang terjadi pada tahun 2018, dan baru-baru ini pula tanggal 02 Agustus 2019 mengalami gempa yang berpotensi tsunami. Hal itulah yang mendorong pengurus desa bersama BPBD dijembatani KKM Tematik UNBAJA kelompok 9 beranggotakan 20 orang mahasiswa beserta satu orang DPL Telly Rosdiyani membuat program kerja yang sifatnya bisa bermanfaat bagi daerah pengabdian terhadap masyarakatnya.

Ketua penyelenggara seminar M.Fahmi Azis mengatakan syukur Alhamdulillah dapat mendatangkan narasumber Toni, Sugi dan Joni sebagai perwakilan dari BPBD untuk dapat memberikan ilmu pengetahuannya tentang penanggulangan bencana, yang sangat diperlukan pada masyarakat saat ini. Sehingga warga pun sangat merespon dengan baik mengikuti acara seminar tersebut, bahkan tamu undangan kelompok 10 Tematik KKM UNBAJA beserta warganya yang ada di Desa Karang Suraga dan Mahasiswa dari UIN (Universitas Islam Negri)Serang kebetulan bersamaan sedang berlangsung pelaksanaan KKM. Joni selaku koordinator pusat pengendalian operasi penanggulangan bencana (Pusdalops- $\mathrm{Pb}$ ) menyampaikan tentang penanggulangan bencana gempa bumi dan tsunami. Beliau menjelaskan tentang cara bersikap ketika terjadi gempa bumi, 
langkah apa yang harus dilakukan ketika terjadi gempa bumi salah satunya adalah dengan mengenali jenis gempa bumi tersebut.
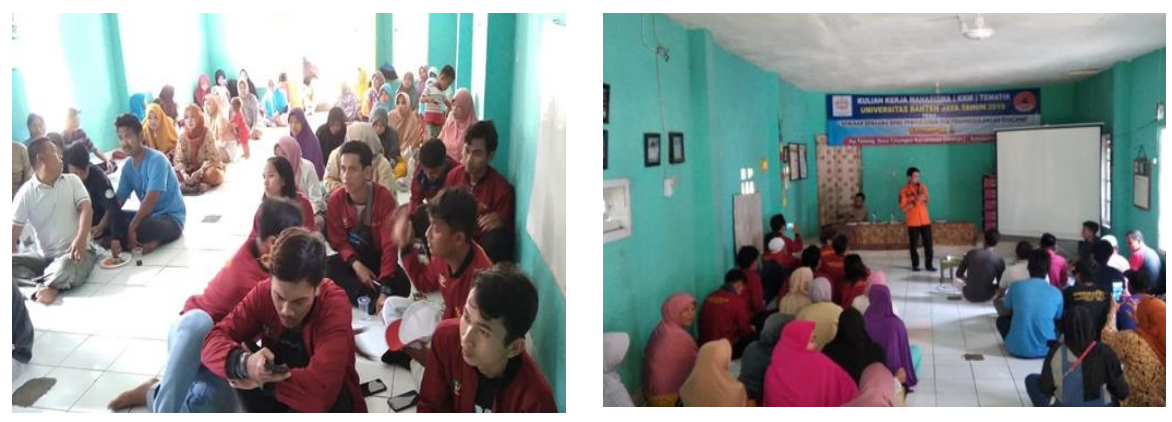

Gambar 2. Penyampaian Materi Oleh BPBD

Beliau juga menegaskan bahwa dengan banyak mengetahui apa yang harus dilakukan ketika terjadi bencana, maka besar kemungkinan akan selamat dari bencana tersebut. Joni pun menambahkan Cara bersikap ketika terjadi tsunami dan cara mengenal tanda-tanda terjadinya tsunami, ciri maupun beberapa tanda-tanda akan terjadinya tsunami dipaparkan diantaranya: Air laut surut bisa sampai 1$2 \mathrm{~km}$ kemudian bisa dilihat dari tingkah laku aneh hewan seperti burung di pantai dan hewan yang lainnya. Setelah pemaparan materi selesai di sampaikan, diberikan kesempatan untuk sesi tanya jawab dari warga. Tumbuh pemahaman dapat menumbuhkan rasa gotong royong saling kerja sama antara tetangga, serta dapat mengetahui dan menyimpan nomor kontak informasi penangulangan bencana yang telah di informasikan.

Begitu besar harapan manfaat yang dapat diambil dari seminar ini acara ditutup dengan rasa syukur kepada tuhan. Doa dipanjatkan dipimpin langsung oleh sesepuh masyarakat kampung Teneng Abah Rasman.

\section{Simulasi Pelatihan Kesiapsiagaan Tanggap Bencana}

Dalam meningkatkan pemahaman terhadap kesiapsiagaan bencana, dilakukan dengan memberikan gambaran terhadap warga dilakukan simulasi pelatihan, kegiatan ini berupa demontrasi/drama dalam persiapan penyelamatan diri. Demontrasi ini dilaksanakan oleh mahasiswa pendamping serta tim pemateri Pusdalops-Pb dan BPBD beserta warga kampung Teneng, dalam kegiatan acara ini dibarengi diselingi interaktif tanya jawab dari masyarakat.

Tim mahasiswa KKM yang sudah diberikan pelatihan terlebih dahulu pada kegiatan pembekalan. Sehingga pada saat kegiatan simulasi pelaksanaan, mahasiswa bisa menjadi 
pendamping dan dapat memberikan penjelasan maupun arahan bagi masyarakat. Mahasiswa yang terlibat pada kegiatan KKM ini terdiri dari lintas fakultas dan program studi yang telah mengontrak Mata Kuliah KKM di UNBAJA.

\section{KESIMPULAN}

Setelah dilakukan kegiatan Kuliah Kerja Mahasiswa - Tematik berbasis Problem Solving untuk memecahkan masalah dengan tema "Teknologi Tepat Guna, Kewirausahaan dan Pengembangan Budaya Banten “Edukasi Kesiapsiagaan Bencana Kampung Teneng Kabupaten Serang Dapat Meningkatkan Pemahaman Prosedur Penyelamatan diri.

\section{UCAPAN TERIMAKASIH}

Ucapan terimakasih disampaikan kepada ;

1. Ketua LPPM Universitas banten Jaya yang telah memberikan kesempatan dan dukungan untuk melaksanakan kegiatan Kuliah Kerja Nyata dengan tema "Teknologi Tepat Guna, Kewirausahaan dan Pengembangan Budaya Banten "Sebagai Upaya meningkatkan kebersamaan dan keterampilan masyarakat desa terhadap kesiapsiagaan tanggap bencana”.

2. Ketua Pelaksana KKM atas kesempatan kepada KKM UNBAJA dalam hal Pengabdian

3. Camat Cinangka yang telah memberikan kesempatan dan dukungan dalam program pengabdian desa.

4. Kepala Desa Cinangka yang telah bekerjasama dan memberikan dorongan untuk dapat melakukan pengabdian di desa tersebut.

5. Mitra BPBD dan Pusdalops-Pb yang telah memberikan materi untuk pemahaman kesiapsiagaan tanggap bencana.

\section{DAFTAR PUSTAKA}

LPPPM. (2019). Kuliah Kerja Mahasiswa (KKM) TEMATIK. Univeritas Banten Jaya.

Pahleviannur, M. R. (2019). Edukasi Sadar Bencana Melalui Sosialisasi Kebencanaan Sebagai Upaya Peningkatan Pengetahuan Siswa terhadap Mitigasi Bencana. Jurnal Pendidikan Ilmu Sosial, 29(1), 49-55. https://doi.org/10.23917/jpis.v29i1.8203.

Roskusumah, T. (2013). Komunikasi Mitigasi Bencana oleh Badan Geologi KESDM di Gunung Api Merapi Prov. D. I. Yogyakarta. Jurnal Kajian Komunikasi, 1(1), 59. https://doi.org/10.24198/jkk.v1i1.6031. 
Suriadi, A. B., Arsyad, M. \& Riadi, B. (2008). Pedoman Komando Tanggap Darurat Bencana. BNPB, 13(2), 57-63. https://doi.org/10.1017/CBO9781107415324.004. 